ISSN 0258-7122 (Print), 2408-8293 (Online)

Bangladesh J. Agril. Res. 42(2): 353-362, June 2017

\title{
EFFECTIVENESS OF SOME SELECTED INSECTICIDES AND BOTANICALS AGAINST OKRA SHOOT AND FRUIT BORER
}

\author{
M. A. MAZED ${ }^{1}$, M. Z. ALAM ${ }^{2}$, M. R. U. MIAH ${ }^{2}$ \\ M. S. HOSSAIN ${ }^{2}$ AND M. A. AWAL ${ }^{1}$
}

\begin{abstract}
An experiment was conducted to evaluate the effectiveness of some selected insecticides and botanicals against okra shoot and fruit borer Earias vittella $\mathrm{F}$. under field conditions. The insecticides tested were Relothrin 10EC @ 1 $\mathrm{ml} \mathrm{l}^{-1}$, Marshal 20EC@2 $\mathrm{ml} \mathrm{l}^{-1}$ and Riva $2.5 \mathrm{EC} @ \mathrm{ml} \mathrm{l}^{-1}$; and the botanicals were

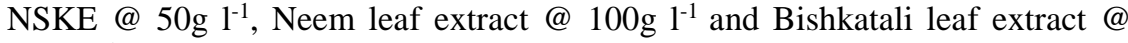

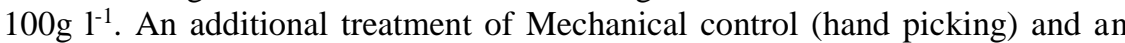
untreated control were maintained in the experiment for comparison. All treatments were applied at 15 days interval. Shoot infestation was the lowest in Marshal 20EC treated plot $(4.34 \%$ at pre-fruiting and $3.55 \%$ at fruiting stage) and the highest was in untreated control plot $(21.4 \%)$. The lowest fruit infestation by okra shoot and fruit borer was obtained with Marshal 20EC $(5.07 \% \mathrm{n} / \mathrm{n}$ and $3.65 \% \mathrm{w} / \mathrm{w})$ followed by Relothrin 10EC $(5.43 \% \mathrm{n} / \mathrm{n}$ and $4.27 \%$ $\mathrm{w} / \mathrm{w})$ and the highest infestation was observed under untreated control plot $(19.67 \% \mathrm{n} / \mathrm{n}$ and $19.81 \% \mathrm{w} / \mathrm{w})$. The reduction of fruit infestation over untreated control ranged from $56.93-81.55 \%$ by number and $43.47-74.22 \%$ by weight. The highest marketable yield $\left(10.46 \mathrm{t} \mathrm{ha}^{-1}\right)$ was obtained in Marshal 20EC treated plot followed by in Relothrin 10EC $10.30 \mathrm{t} \mathrm{ha}^{-1}$ with the maximum benefit cost ratio (BCR) 6.72 .
\end{abstract}

Keywords: Insecticides, botanicals, Earias vittella, okra, Okra shoot and fruit borer.

\section{Introduction}

Okra (Abelmoschus esculentus L.) is an annual widely grown vegetable crop in Bangladesh. But the crop is severely hampered by a number of insect pests, especially okra shoot and fruit borer, jassid and whitefly. Among them, okra shoot and fruit borer, Earias vittella F. (Lepidoptera, Noctuidae) is the most damaging pest of okra (Butani and Jotwani, 1984). Srinivasan and Krishnakumar (1983) reported up to 40-50\% damage of okra fruits by this pest in some areas of South-East Asian countries. In Bangladesh, E. vittella is noted as major insect pest of okra causing tremendous yield losses (Ali, 1992).

Several management practices have been reported to combat this pest (Kabir, 2007; Haque, 1998), however, use of insecticide is the main reliable tool (Parkash, 1988).

${ }^{1}$ Department Agricultural Extension, Dhaka, Bangladesh, ${ }^{2}$ Department of Entomology, Bangabandhu Sheikh Mujibur Rahman Agricultural University (BSMRAU), Gazipur, Bangladesh. 
A wide range of organophosphorus, carbamate and synthetic pyrethroids of various formulations have been recommended to control the pest (Chattopadhyay, 1991; Borah, 1997). Sahoo and Pal (2003) reported that spraying carbosulfan at 15 days interval showed the lowest fruit damage of okra. Ambekar et al. (2000) reported that cypermethrin at $0.1 \%$ showed effective against $E$. vittella and recorded the lowest infestation. Vishwanath and Singh (2008) described that foliar application of Lambda-Cyhalothrin at flowering and fruit initiation stages was the most effective against E. vittella. However, indiscriminate and non-judicious use of insecticides may result in a series problem related to both loss of their effectiveness and in the long run, it develops insect resistance (Alam et al., 2003), pollution (FAO, 2003) and health hazards (Chinniah et al., 1998). Various non-chemical approaches like use of botanicals, clean cultivation, mechanical control like hand picking and destroying of infested plant parts particularly shoots and fruits are common practices used for suppressing the insect pests (Hasan, 1994).

Due to lack of knowledge and unavailability of non-chemical pest management approaches, growers of Bangladesh mostly depend on insecticides to keep the crop production steady. Appropriate knowledge and availability of botanical pest management approaches and their integration with selective chemicals may give better results against okra shoot and fruit borer. Considering the circumstances, the present study was conducted to evaluate the effectiveness of three insecticides and three botanicals for effective and economic management of $E$. vittella in okra field.

\section{Materials and Method}

\section{Experimental site and design}

The study was conducted in the experimental farm of Bangabandhu Sheikh Mujibur Rahman Agricultural University (BSMRAU), Gazipur during March to July 2010. The experiment was laid out in a Randomized Complete Block Design (RCBD) with three replications. The unit plot size was $3 \mathrm{~m} \times 2 \mathrm{~m}$ and separated by $1 \mathrm{~m}$ and block to block distance was $2 \mathrm{~m}$.

\section{Growing of okra}

Seeds of okra cultivar Arka Anamika were soaked in water for 24 hours and sown in the pit in the field. Two to three seeds were sown in each pit maintaining line to line distance of $60 \mathrm{~cm}$ and finally plant to plant distance $40 \mathrm{~cm}$. Each unit plot received 21 plants. Gap filling was done by transplanting seedlings from the stock. Manures and fertilizers were applied according to Rashid (1999) and intercultural operations such as irrigation, weeding, mulching, thinning and other operations were done accordingly. One spray with Imitaf $20 \mathrm{SL} @ 0.25 \mathrm{ml} \mathrm{l}^{-1}$ water within 30 days after seed sowing (DAS) was done to control whitefly (Bemisia tabaci). 


\section{Preparation of botanicals}

Neem seed karnel extract: Mature seeds of neem (Azadirachta indica) were collected, sun dried and grounded into powder. The powder was soaked in water @ $50 \mathrm{~g} / 300 \mathrm{ml}$ of water for overnight. The mixture was filtered through nylon net and maintained the volume of $1000 \mathrm{ml}$.

Biskatali and neem leaf extract: Fresh Bishkatali (Polygonum hydropiper) and neem leaves (Azadirachta indica) were collected for the preparation of leaf extract one day before application. The leaves were cut into small pieces and 500g leaves were blended thoroughly in an electric blender. The blended leaves were mixed with two liters of water and the mixture was kept overnight to enhance extraction. The mixture was then sieved and maintained the volume at 5 liters.

\section{Application of treatments}

The experimental field was monitored regularly to observe the initiation of infestation When the pest caused approximately $2 \%$ shoot infestation, the application of treatments was started. The experimental treatments were Marshal (Carbosulphan) 20EC @ 2 $\mathrm{ml} \mathrm{l}^{-1}$, Ripcord (Cypermethrin) 10EC @ 1 $\mathrm{ml} \mathrm{l}^{-1}$ water, Riva 2.5EC (Lambda-cyhallothrin) @ $1 \mathrm{ml} \mathrm{l}^{-1}$ water, Neem seed kernel extract

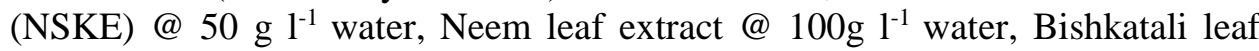

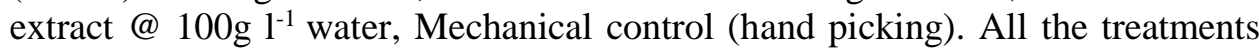
were applied at 15 days interval and repeated 4 times up to last harvest.

\section{Collection and analysis of data}

Data on shoot infestation and fruit yield by number were recorded. Total number of shoots and the number of infested shoots were recorded from 5 plants randomly selected in each plot at before flowering, after flowering to fruit initiation and at fruiting stages at 7 days interval. The number of healthy and infested fruits and their weight per plot were recorded at each harvest. The infestation of the pest was expressed in percentage based on total number of shoot and fruit $(\mathrm{n} / \mathrm{n})$ and weight $(\mathrm{w} / \mathrm{w})$ of fruit.

The cumulative yield (g) per plot of healthy as well as infested fruits was computed. The final yield was expressed in ton per hectare. For economic analysis, BCR was calculated on the basis of total expenditure of the respective spray schedule along with the total return from that particular spray schedule. The data were analyzed statistically by analysis of variance (ANOVA) and the means were separated by using Duncan's Multiple Range Test (DMRT).

\section{Results and Discussion}

\section{Rate of shoot infestation}

Effects of various treatments on percent shoot infestation by okra shoot and fruit borer at pre fruiting and fruiting stages is presented in Table 1. Shoot infestation 
ranged $4.34-21.43 \%$ at pre-fruiting and $3.55-21.42 \%$ at fruiting stages under different treatments. The highest shoot infestation was observed in untreated control plot and the lowest infestation was obtained with Marshall spray at both pre-fruiting and fruiting stages. The reduction of shoot infestation over untreated control ranged from 40.32 to $79.75 \%$ at pre-fruiting stage and 49.81 to $83.41 \%$ at fruiting stage. The highest reduction in shoot infestation was achieved with Marshal 20EC treated plot followed by Relothrin 10EC (76.33\%), Riva 2.5EC (69.03\%), NSKE (65.70\%), Neem leaf extract (60.84\%) and Bishkatali leaf extract $(52.92 \%)$ treated plots.

At fruiting stage, reduction in shoot infestation over control ranged from 49.81$83.41 \%$ under different treatments including untreated control. The highest reduction was also obtained with Marshal 20EC treated plot followed by Relothrin 10EC (79.24\%), Riva 2.5EC (76.99\%), NSKE (69.89\%), Neem leaf extract and Bishkatali leaf extract (58.30\%) sprayed plots. The lowest shoot infestation was recorded from Marshal 20EC (3.55\%) treated plot, which was statistically similar to Riva 2.5EC (4.93\%) and Relothrin 10EC (4.45\%) treated plots. The higher shoot infestation was recorded from mechanical control plot $(10.75 \%)$ which was significantly similar with Bishkatali leaf extract $(8.93 \%)$ and Neem leaf extract $(7.45 \%)$ treated plots.

Results revealed that among the treatments the efficacy of insecticides was better than the three plant extracts. Among the insecticides, the most effective was Marshal 20EC followed by Relothrin 10EC and Riva 2.5EC. Of the three botanicals, Neem seed kernel extract (NSKE) was most effective followed by Neem leaf extract and Bishkatali leaf extract (Table 1). In a similar study, In-Hu et al. (2004) reported that Proclaim showed $87.00 \%$ shoot infestation reduction over control. Islam et al. (1999) recommended that the minimum acceptable level of shoot infestation reduction over control was $80.00 \%$.

Table 1. Effect of chemical, botanical and mechanical treatments on the rate of shoot infestation by okra shoot and fruit borer at pre-fruiting and fruiting stages

\begin{tabular}{l|l|c|c|c}
\hline \multirow{2}{*}{\multicolumn{1}{c|}{ Treatments }} & \multicolumn{2}{c|}{ Pre-fruiting stage } & \multicolumn{2}{c}{ Fruiting stage } \\
\cline { 2 - 5 } & $\begin{array}{c}\text { \% Shoot } \\
\text { infestation }\end{array}$ & $\begin{array}{c}\text { \% Infestation } \\
\text { reduction over } \\
\text { control }\end{array}$ & $\begin{array}{c}\text { \% Shoot } \\
\text { infestation }\end{array}$ & $\begin{array}{c}\text { \% Infestation } \\
\text { reduction over } \\
\text { control }\end{array}$ \\
\hline Marshal 20EC & $4.34 \mathrm{c}$ & 79.75 & $3.55 \mathrm{f}$ & 83.41 \\
Riva 2.5EC & $6.63 \mathrm{bc}$ & 69.03 & $4.93 \mathrm{def}$ & 76.99 \\
Relothrin 10EC & $5.07 \mathrm{bc}$ & 76.33 & $4.45 \mathrm{ef}$ & 79.24 \\
Neem seed kernel extract & $7.35 \mathrm{bc}$ & 65.70 & $6.45 \mathrm{cde}$ & 69.89 \\
Neem leaf extract & $8.39 \mathrm{bc}$ & 60.84 & $7.54 \mathrm{~cd}$ & 65.23 \\
Bishkatali leaf extract & $10.00 \mathrm{bc}$ & 52.92 & $8.93 \mathrm{bc}$ & 58.30 \\
Mechanical control & $12.79 \mathrm{~b}$ & 40.32 & $10.75 \mathrm{~b}$ & 49.81 \\
Untreated control & $21.43 \mathrm{a}$ & - & $21.42 \mathrm{a}$ & - \\
\hline CV $(\%)$ & 8.59 & - & 16.75 & - \\
\hline
\end{tabular}

Means within the same column with a common letter(s) do not differ significantly $(\mathrm{P}=0.05)$ according to DMRT. 


\section{Rate of fruit infestation (n/n and w/w)}

The lowest rate of fruit infestation $(\mathrm{n} / \mathrm{n})$ was obtained in plots sprayed with Marshal 20EC (5.07\%) followed by Relothrin 10EC (5.43\%) and these were statistically similar but significantly lower compared to other treatments (Table 2). The rate of fruit infestation obtained $6.68 \%$ in Riva $2.5 \mathrm{EC}, 7.46 \%$ in Neem seed kernel extract, $9.99 \%$ in Neem leaf extracts, $10.25 \%$ in Bishkatali leaf extract treated plots. The highest rate of fruit infestation $(\mathrm{n} / \mathrm{n})$ was obtained in untreated control plots (19.67\%) followed by Mechnical control plots (11.12\%) and these were statistically different from each other.

The rate of reduction of fruit infestation $(\mathrm{n} / \mathrm{n})$ over untreated control was obtained with Marshal 20EC (74.22\%) followed by Relothrin 10EC (72.38\%), Riva 2.5EC (66.00\%), NSKE (62.04\%), Neem leaf extracts (49.21\%). The least effective treatments to reduce fruit infestation were Mechnical control (43.47\%) followed by Bishkatali leaf extract (47.90\%) (Table 2).

The lowest fruit infestation (w/w) was obtained in plots sprayed with Marshal 20EC $(3.65 \%)$ followed by Relothrin 10EC (4.27\%) and Riva 2.5EC (5.51\%) differences were statistically significant. The rate of fruit infestation obtained $5.76 \%$ in Neem seed kernel extract, $7.37 \%$ in Neem leaf extracts, $7.83 \%$ in Bishkatali leaf extract treated plots. The highest rate of fruit infestation $(\mathrm{w} / \mathrm{w})$ was obtained in untreated control plots (19.81\%) followed by Mechnical control plots $(8.53 \%)$ and these were statistically different with each other.

Reduction $(\% \mathrm{w} / \mathrm{w})$ of fruit infestation over untreated control ranged from 56.93$81.55 \%$. The highest reduction was achieved with Marshal 20EC followed by Relothrin 10EC (78.41\%) and Riva 2.5EC (72.17\%). Among the botanicals, $70.91,62.76$ and $60.46 \%$ reduction was achieved with foliar spray of NSKE, Neem leaf extract and Bishkatali leaf extract, respectively. The lowest reduction of $56.93 \%$ was obtained with Mechanical control (Table 2).

In a similar type of study, Pawar et al. (1988) reported that single spray of Endosulfan with concentration $500 \mathrm{~g} \mathrm{ha}^{-1}$ followed by 3 applications of Cypermethrin or Fenvalerate at $50 \mathrm{~g} \mathrm{ha}^{-1}$ at an interval of 14 days was the most effective for the control of E. vitella infesting okra. On the other hand, Alagar and Sivasubramaniam (2006) recorded the highest percentage of okra fruit damage reduction $(48.93 \%)$ and higher yield $\left(14.75\right.$ tha $\left.^{-1}\right)$ with 5\% NSKE.

Among the materials, Marshal 20EC was noted as the most effective material to suppress okra shoot and fruit borer. Similar study was conducted by Kabir (2007) and obtained $12.76 \%-92.52 \%$ reduction in fruit infestation over control. In the present study, the reduction of infested fruit over untreated control was higher (72.17-81.55\%) in three insecticide treated plots compared to botanicals (60.46$70.91 \%)$. 
Table 2. Effect of insecticides, botanicals and mechanical treatments on rate of fruit infestation by okra shoot and fruit borer

\begin{tabular}{l|c|c|c|c}
\hline \multirow{2}{*}{\multicolumn{1}{c}{ Treatments }} & \multicolumn{2}{|c|}{ Rate of infestation $(\mathrm{n} / \mathrm{n})$} & \multicolumn{2}{c}{ Rate of infestation (w/w) } \\
\cline { 2 - 5 } & $\begin{array}{c}\% \\
\text { Infestation }\end{array}$ & $\begin{array}{c}\text { \% Reduction } \\
\text { over untreated } \\
\text { control }\end{array}$ & \% Infestation & $\begin{array}{c}\% \text { Reduction } \\
\text { over untreated } \\
\text { control }\end{array}$ \\
\hline Marshal 20EC & $5.07 \mathrm{f}$ & 74.22 & $3.65 \mathrm{f}$ & 81.55 \\
Riva 2.5EC & $6.68 \mathrm{e}$ & 66.00 & $5.51 \mathrm{~d}$ & 72.17 \\
Relothrin 10EC & $5.43 \mathrm{f}$ & 72.38 & $4.27 \mathrm{e}$ & 78.41 \\
Neem seed kernel extract & $7.46 \mathrm{~d}$ & 62.04 & $5.76 \mathrm{~d}$ & 70.91 \\
Neem leaf extract & $9.99 \mathrm{c}$ & 49.21 & $7.37 \mathrm{c}$ & 62.76 \\
Bishkatali leaf extract & $10.25 \mathrm{c}$ & 47.90 & $7.83 \mathrm{c}$ & 60.46 \\
Mechanical control & $11.12 \mathrm{~b}$ & 43.47 & $8.53 \mathrm{~b}$ & 56.93 \\
Untreated control & $19.67 \mathrm{a}$ & - & $19.81 \mathrm{a}$ & - \\
\hline \multicolumn{1}{c}{$\mathrm{CV}(\%)$} & 7.06 & - & 6.83 & - \\
\hline
\end{tabular}

Means within a column with a common letter(s) do not differ significantly $(\mathrm{P}=0.05)$ according to DMRT.

\section{Yield of okra ( $\left(\right.$ ha $\left.^{-1}\right)$}

The plots treated with Marshal 20EC produced significantly the highest marketable yield of okra per hectare $\left(10.46 \mathrm{t} \mathrm{ha}^{-1}\right)$, which was statistically similar to that obtained from the Relothrin 10EC $\left(10.30 \mathrm{t} \mathrm{ha}^{-1}\right)$ treated plot. The marketable fruit yield of okra was obtained from the plot treated with NSKE $\left(9.89 \mathrm{t} \mathrm{ha}^{-1}\right)$ which was significantly different from all other treatments. The yield in Riva 2.5EC treated plot was $8.50 \mathrm{t} \mathrm{ha}^{-1}$ and Neem leaf extract treated plot produced $7.92 \mathrm{t} \mathrm{ha}^{-1}$, were significantly different from each other and the rest of the treatments. Comparatively the lower yield of marketable fruit was obtained in Bishkatali leaf extract (7.34 $\left.\mathrm{t} \mathrm{ha}^{-1}\right)$ treated plot and Mechanical control (7.35 tha$\left.{ }^{1}\right)$ plot which were statistically similar. The lowest marketable yield was harvested from untreated control plot $\left(6.47 \mathrm{t} \mathrm{ha}^{-1}\right)$ and this was significantly lower compared to all other treatments (Table 3 ).

Significantly the highest infested fruit yield of okra $\left(1.60 \mathrm{t} \mathrm{ha}^{-1}\right)$ was obtained in untreated control plot followed by mechanical control plot $\left(0.68 \mathrm{t} \mathrm{ha}^{-1}\right)$ which was similar to Neem leaf extract $\left(0.63 \mathrm{t} \mathrm{ha}^{-1}\right)$ treated plot. Statistically similar infested fruit yield was obtained in NSKE $\left(0.60 \mathrm{t} \mathrm{ha}^{-1}\right)$ treated plot, Bishkatali leaf extract $\left(0.62 \mathrm{t} \mathrm{ha}^{-1}\right)$ and also Neem leaf extract treated plots. The lowest infested fruit yield was obtained in Marshal 20EC $\left(0.40 \mathrm{t} \mathrm{ha}^{-1}\right)$, which was significantly different from all other treatments. The lower infested fruit yield was obtained in Riva $\left(0.49 \mathrm{t} \mathrm{ha}^{-1}\right)$ sprayed plot, which was followed by Relothrin 10EC $\left(0.46 \mathrm{t} \mathrm{ha}^{-1}\right)$ and they were statistically similar. 
The percent increase of marketable yield over untreated control plot was the highest $(61.67 \%)$ in the plot sprayed with Marshal 20EC followed by Relothrin $10 \mathrm{EC}(59.20 \%)$ treated plot and NSKE (52.90\%). The lowest percent increase in healthy fruit yield over untreated control was Bishkatali leaf extract $(13.45 \%)$ treated plot which was followed by mechanical control plot (13.65\%). Percent marketable yield increase over untreated control was lower in Riva 2.5EC (31.48\%) and Neem leaf extract $(22.46 \%)$.

The present finding of yield increase over control may be discussed with those of other authors. Choudhury and Dadheech (1989) reported that cypermethrin sprayed at weekly interval starting from the first flowering provided $25.00 \%$ increased yield over untreated control. Sardana and Kumar, 1989 observed that weekly application of Neem (Azadirachta indica) oil at 2\% was effective for controlling $E$. vittella on okra. Neem oil was found as effective as Monocrotophos at $0.05 \%$, and can therefore, be recommended for use in an integrated control scheme against this pest. In the present study, the NSKE provided appreciable yield increase (52.90\%) over control compared to Relothrin (59.20\%) and Marshal (61.67\%). But it was considerably higher than that of Riva 2.5EC (31.48\%). So, use of NSKE may be an alternate tools for safer management of okra shoot and fruit borer.

Table 3. Okra fruit yield obtained by shoot and fruit borer management using insecticides, botanicals and mechanical treatments

\begin{tabular}{l|c|c|c}
\hline \multirow{2}{*}{\multicolumn{1}{c}{ Treatments }} & \multicolumn{3}{c}{ Yield (t ha-1) } \\
\cline { 2 - 4 } & Marketable & Infested & $\begin{array}{c}\% \text { marketable yield increase } \\
\text { over untreated control }\end{array}$ \\
\hline Marshal 20EC & $10.46 \mathrm{a}$ & $0.40 \mathrm{e}$ & 61.67 \\
Riva 2.5EC & $8.50 \mathrm{c}$ & $0.49 \mathrm{~d}$ & 31.48 \\
Relothrin 10EC & $10.30 \mathrm{a}$ & $0.46 \mathrm{~d}$ & 59.20 \\
Neem seed kernel extract & $9.89 \mathrm{~b}$ & $0.60 \mathrm{c}$ & 52.90 \\
Neem leaf extract & $7.92 \mathrm{~d}$ & $0.63 \mathrm{bc}$ & 22.46 \\
Bishkatali leaf extract & $7.34 \mathrm{e}$ & $0.62 \mathrm{c}$ & 13.45 \\
Mechanical control & $7.35 \mathrm{e}$ & $0.68 \mathrm{~b}$ & 13.65 \\
Untreated Control & $6.47 \mathrm{f}$ & $1.60 \mathrm{a}$ & - \\
\hline CV (\%) & 6.90 & 6.05 & - \\
\hline
\end{tabular}

Means within the same column with a common letter(s) do not differ significantly $(\mathrm{P}=0.05)$ according to DMRT.

\section{Economic analysis of different control measures}

The management cost of different treatments used against okra shoot and fruit borer was calculated and presented in Table 4. The highest gross return of Tk. 2,61,500.00 $\mathrm{ha}^{-1}$ was obtained with the Marshal 20EC followed by Relothrin 10EC (Tk. 2,57,500.00), NSKE (Tk. 2,47,250.00), Riva 2.5EC (Tk. 2,12,675.00), Neem leaf extract (Tk. 1,98,075.00), mechanical control (Tk. 1,83,825.00) and Bishkatali leaf extract (Tk. 1,83,500.00). 
The highest net return of Tk. 2,47,300.00 per hectare was obtained with the Marshal 20EC followed by Relothrin 10EC (Tk. 2,45,100.00), NSKE (Tk. 2,31,350.00), Riva 2.5EC (Tk. 2,03,275.00), Neem leaf extract (Tk. 1,86,395.00), mechanical control (Tk. 1,76,625.00) and Bishkatali leaf extract (Tk. $1,74,484.00)$.

The highest adjusted net return of Tk. 85,550.00 ha-1 was obtained with the Marshal 20EC followed by Relothrin 10EC (Tk. 83,350.00), NSKE (Tk. 69,600.00), Riva 2.5EC (Tk. 41525.00), Neem leaf extract (Tk. 24,645.00), mechanical control (Tk. 14,875.00) and Bishkatali leaf extract (Tk. 12,734.00) (Table 4).

The highest benefit cost ratio (6.72) was obtained with Relothrin 10EC followed by Marshal 20EC (6.02), Riva 2.5EC (4.42), NSKE (4.37), Neem leaf extract (2.11), Mechanical control (2.07) and Bishkatali leaf extract (1.41). The cause of lower of these treatments were due to comparatively lower yield and higher cost of management against okra shoot and fruit borer (Table 4).

The economics of pest management of okra shoot and fruit borer were studied by Srinivasan and Krishnakumar (1983) in Karnataka, India, for 3 growing seasons. Disulfoton granules@ $1 \mathrm{~kg}$ a.i. ha ${ }^{-1}$ applied at the time of sowing, followed by $1 \%$ carbaryl sprays at 40,50 and 60 days after germination, gave the maximum crop yield and net income.

The findings of the present study indicated that the insecticide Relothrin 10EC, Marshal 20EC and Riva 2.5EC are effective to manage infestation of okra shoot and fruit borer in okra. The result of this study reveal that NSKE showed effective result in suppressing okra shoot and fruit borer infestation and also cost effective. Although it provides moderate level of economic benefit but it has no hazard to health and environment compared to insecticide application.

Table 4. Benefit cost ratio analysis of selected insecticides and botanicals along with mechanical control for the management of okra shoot and fruit borer

\begin{tabular}{l|l|l|lc|cc}
\hline \multicolumn{1}{c|}{ Treatments } & $\begin{array}{l}\text { Management } \\
\text { cost (Tk) }\end{array}$ & $\begin{array}{l}\text { Gross return } \\
(\mathrm{Tk})\end{array}$ & $\begin{array}{l}\text { Net return } \\
(\mathrm{Tk})\end{array}$ & $\begin{array}{l}\text { Adjusted net } \\
\text { return (Tk) }\end{array}$ & BCR \\
\hline Marshal 20EC & 14200.00 & 261500.00 & 247300.00 & 85550.00 & 6.02 \\
Riva 2.5EC & 9400.00 & 212675.00 & 203275.00 & 41525.00 & 4.42 \\
Relothrin 10EC & 12400.00 & 257500.00 & 245100.00 & 83350.00 & 6.72 \\
$\begin{array}{l}\text { Neem seed kernel } \\
\text { extract }\end{array}$ & 15900.00 & 247250.00 & 231350.00 & 69600.00 & 4.37 \\
Neem leaf extract & 11680.00 & 198075.00 & 186395.00 & 24645.00 & 2.11 \\
$\begin{array}{l}\text { Bishkatali leaf } \\
\text { extract }\end{array}$ & 9016.00 & 183500.00 & 174484.00 & 12734.00 & 1.41 \\
Mechanical control & 7200.00 & 183825.00 & 176625.00 & 14875.00 & 2.07 \\
Untreated control & 0.00 & 161750.00 & 161750.00 & - & - \\
\hline
\end{tabular}




\section{References}

Alagar, M. and P. Sivasubramanian. 2006. Field efficacy of botanicals, insecticides and their combination against major pests of okra. Indian J. of Entomol. 68(4): 369-374.

Alam, S.N., M.A. Rashid, F.M.A. Rouf, R.C. Jhala, J.R. patel, S. Satpathy, T.M. Shivalingaswamy, S. Rai, I. wahundeniya, A. Cork, C. Ammaranan, and N.S. Talekar. 2003. Development of an integrated pest management strategy for eggplant shoot and fruit borer in south Asia. Technical Bull. 28. AVRDC-The world Vegetable centre, Shanhua, Taiwan. 66p.

Ali, M.I. 1992. Seasonal occurrence of different cotton bolloworms on cotton in Bangladesh. Bangladesh J. Entomol. $2(1 \&$ 2):1-7.

Ambekar, J.S., A.S. Pawar and M.V. Sakhare. 2000. Bio-efficacy of neem certain products against okra fruit borer. J. Maharashtra Agril. Univ. Pune, India. 25(1): 42-43.

Borah, R.K. 1997. Effect of insecticides on pest incidence in cucumber (Cucumis sativus) in hill zone of Assam. Indian J. Agric. Sci. 67(8): 332-333.

Butani, D.K. and M.G. Jotwani. 1984. Insects in vegetables. Periodical Expert Book Agency. Vivek-Vihar, Delhi (India). Pp. 45-66.

Chattopadhyay, P. 1991. Keetatatta, keetadaman O Shasya sanrakshan. West Bengal state Book board, Arjo Mansion (9th floor), 6A. Raja Subodh Mollick Sqmare, Calcutta 70013, India. $2^{\text {nd }}$ Edition. (in Bangla). 375p.

Chaudhury, H.R. and L.N. Dadheech. 1989. Incidence of insects attacking okra and the avoidable losses caused by them. Ann. Arid Zone. 28 (3-4): 305-307.

Chinniah, C., S. Kuttalam and A. Regupathy. 1998. Harvest time residue oflindane and chlorpyriphos in paddy. Pestic. Res. J. 10(1):91-94.

FAO (Food and Agriculture Organization). 2003. Intercountry programme for integrated pest management in vegetables in South and South-East Asia. Egg plant integrated pest management: An ecological guide. 177p

Haque, M.A. 1998. Seasonal abundance and management of okra shoot and fruit borer in summer. M.S. Thesis, BSMRAU, Gazipur, Bangladesh. Pp 27-45

Hassan, S.A. 1994. Strategies to select Trichogramma species for use in biological control. In: Biological control with egg parasitoids, (Eds.): E. Wajinberg and S.A. Hassan. Oxon, U.K.: CAB International. 557p.

In-Hu, C., J. Yong-Seok, K. Gil-Hah and K. Jeong-Wha. 2004. Control effects of some insecticides on different stages of the stone leek leafminer, Liriomyza chinensis kato (Diptera: Agromyzidae). Korean Appl. Entom. 43(2): 169-173.

Islam, M.N., N.K. Dutta and M.A. Karim. 1999. Efficacy of different insecticides for the control of okra shoot and fruit borer, Earias vittella F. Annual Report. 1998-99. BARI, Joydevpur, Gazipur, Bangladesh. Pp 33-34.

Kabir, M.R. 2007. Effectiveness of some insecticides for the management of okra shoot and fruit borer (Earias vittella F.). M.S. Thesis, BSMRAU, Gazipur, Bangladesh. Pp 33-48

Parkash, O. 1988. Schedule of insecticidal application against insect pest complex of brinjal with special reference to brinjal shoot \& fruit borer, Leucinodes orbonalis Guen. Indian J. Ent. 50(1): 16-19. 
Pawer, D.B., P.N. Kale, D.S. Ajri and K.E. Lawande. 1988. Chemical control of fruit borer of okra. J. Maharashtra Agril. Univ., 13(1): 115-117.

Rashid, M.M. 1999. Bibidh shabji (Dheros), In: Shabji Biggan (In Bangla). pp. 466-471

Sahoo, S.K. and P.K. Pal. 2003. Effect of alternate use of pesticides on shoot and fruit borers of okra. Environ. and Ecol. 21(4): 960-963.

Srinivasan, K and N.K. Krisnakumar. 1983. Studies on the extent of loss and economies of pest management in okra. Tropic. pest manage. 29(4): 363-370.

Vishwanath and J.P. Singh, 2008. Evaluation of insecticides and Neem formulations for control of Earias vittella of okra. Annals Plant Protect. Sci. 16(1): 206-207. 